\title{
Antibacterial Effectiveness of Morinda Citrifolia L. Extract on Salmonella Typhi Bacteria Using Serial Dilution Method with 15 - 60 Minutes Contact Time
}

\author{
Wawan Sofwan Zaini*
}

\section{Wawan Sofwan Zaini*}

Poltekkes Kemenkes Banten, INDONESIA.

\section{Correspondence}

\section{Wawan Sofwan Zaini}

Poltekkes Kemenkes Banten, INDONESIA. E-mail:wansz.wsz@gmail.com

History

- Submission Date: 24-02-2021;

- Review completed: 15-03-2021;

- Accepted Date: 29-03-2021.

DOI : 10.5530/pj.2021.13.107

Article Available online

http://www.phcogj.com/v13/i4

\section{Copyright}

(c) 2021 Phcogj.Com. This is an openaccess article distributed under the terms of the Creative Commons Attribution 4.0 International license.

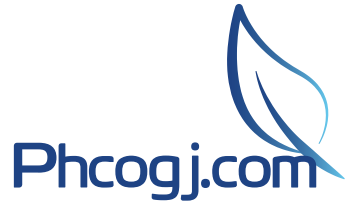

\begin{abstract}
Noni fruit (Morinda citrifolia L.) contains phenol and flavonoid compounds which can function as natural antibacterials with the highest phenol content obtained from ripe Morinda citrifolia $L$. fruit. Phenolic compounds have been widely studied as disinfectants against broadspectrum antibacterials, namely Gram-positive and Gram-negative bacteria. This study aims to determine the effectiveness of the inhibitory power of ripe Morinda citrifolia L. extract against the growth of gastroenteritis-causing bacteria with the serial dilution method at concentrations of $40 \%, 60 \%, 80 \%$, and $100 \%$ with variations in a contact time of 15 ', 30 ', 45 'and 60 '. Then proceed with a concentration of $10 \%, 20 \%, 30 \%$, and $40 \%$ with the same variation in contact time. The results showed that all concentrations of ripe Morinda citrifolia $L$. extract and the variation in contact time could inhibit the growth of S. Typhi bacteria with a minimum inhibitory concentration at a concentration of $10 \%$ with a contact time of 15 minutes. It needs to be continued with a toxicity test before it is used in the community.

Key words: Morinda citrifolia L., Serial dilution, S. Typhi.
\end{abstract}

\section{BACKGROUND}

Morinda citrifolia $L$. is a plant used in herbal medicine for 2000 years. Morinda citrifolia $L$. also known as Pace or Noni. This fruit is green with a cocoon shape that has many eyes. This pungent fruit tastes very bitter. ${ }^{1}$ However, the fruit contains several substances that are nutritious for treatment. ${ }^{2}$ According to Tjandra Srijaja Prajonggo, Chairman of the Association of Herbal Medicine Entrepreneurs, the properties of Morinda citrifolia $L$. have been known for decades from generation to generation. ${ }^{3}$ Morinda citrifolia $L$. is believed to treat various diseases from diarrhea to tumors. ${ }^{4}{ }^{5}$

The older the Morinda citrifolia L. fruit is, the stronger its properties are in curing diseases. ${ }^{3}$ Morinda citrifolia $L$. unripe is dark green, hard, and odorless. Half-ripe Morinda citrifolia $L$. is light green, slightly soft, and odorless, while the ripe Morinda citrifolia L. is greenish-white, soft, and has a distinctive odor. Morinda citrifolia $L$. contains phenol and flavonoid compounds which can function as natural antibacterials with the highest phenol content obtained from ripe Morinda citrifolia $L$ fruit. Phenolic compounds have been widely studied as disinfectants against broadspectrum antibacterials, namely Gram-positive and Gram-negative bacteria. Quantitative analysis of the total phenol equivalent of gallic acid in Morinda citrifolia L. raw 2.24\%, Half-ripe Morinda citrifolia L. 3.65\%, and Morinda citrifolia L. ripe 6.18\%. ${ }^{6}$

Based on the research results, it was found that the minimum inhibitory content of Morinda citrifolia $L$. juice was ripe against Methicillin-Resistant Staphylococcus aureus bacteria at a concentration of $30 \%$. In comparison, the minimum kill rate occurred at a concentration of $35 \%$. The antibacterial power of ripe Morinda citrifolia $L$. juice occurs because Morinda citrifolia L. contains antibacterial substances, namely flavonoids, terpenoids, anthraquinones, alizarin, and acubin compounds that can fight Staphylococcus aureus, Bacillus subtilis, Protens morganii, Pseudomonas, Escherichia coli.

Based on the description, it is necessary to research the ripe Morinda citrifolia $L$. extract with different concentration variations and contact times against bacteria that cause gastrointestinal infections using the serial dilution method.

\section{METHOD}

This research is a laboratory experiment. The research was conducted for 16 weeks. The tools used in this research were incubator, sterile measuring pipette, bulb, $100 \mathrm{~m}$ micropipette, $50 \mathrm{~m}$ micropipette, yellow tip, petri dish, Erlenmeyer $250 \mathrm{ml}$, Erlenmeyer 500 mL. Past loop, oven, cotton ball, nephelometer, hotplate, blender, water bath, sterile test tube, tube rack, beaker, bunsen, coffee paper, mattress strap, stopwatch, autoclave, refrigerator, gauze, Parisian cloth, lighter flames, labels, glass funnels, and markers.

The materials used in the study were ripe Morinda citrifolia L., Salmonella-Shigella Agar, Mueller Hinton Agar, 70\% alcohol, aqua dest, methylated spirits, pure culture of Salmonella typhi, and $0.9 \%$ physiological $\mathrm{NaCl}$.

The data used are primary data obtained from the results of the inhibitory test with various concentrations and contact times of ripe and half- 
ripe Morinda citrifolia $L$. fruit juices against the Salmonella typhi dilution method. This study used a completely randomized design approach. It is repeated according to Federer's formula ${ }^{8}$ :

$(\mathrm{n}-1)(\mathrm{t}-1) \geq 15$

$\mathrm{n}=$ lots of repetitions

$\mathrm{t}=$ treatment, in this case, there are 34 Po treatments (P1i, P2j each with four concentrations and four contact times)

\section{Information:}

Po $=$ The treatment was given sterile aqua dest as a positive control and suspension of Salmonella typhi as a negative control so that two treatments were obtained.

$\mathrm{P} 1 \mathrm{i}=$ The treatment group was given ripe Morinda citrifolia $L$. extract with four concentrations $(100 \%, 80 \%, 60 \%$, and $40 \%)$ and four contact times

(15 minutes, 30 minutes, 45 minutes, and 60 minutes), so we got 16 treatments.

$\mathrm{P} 1 \mathrm{j}=$ The treatment group was given ripe Morinda citrifolia $L$. extract with four concentrations $(10 \%, 20 \%, 30 \%$, and $40 \%)$ and four contact times

(15 minutes, 30 minutes, 45 minutes, and 60 minutes), so we got 16 treatments.

So we get the following equation:

$(\mathrm{r}-1)(\mathrm{t}-1) \geq 15$

$(\mathrm{r}-1)(34-1) \geq 15$

$(\mathrm{r}-1)(33) \geq 15$

$33 r-33 \geq 15$

$33 r \geq 15+33$

$33 r \geq 48$

$\mathrm{r} \geq 1,5$

Based on the calculations obtained, the repetition (replication) was carried out two times.

\section{Examination procedure}

Begins with sterilization of equipment. All equipment used in this study was washed, dried, wrapped using wrapping paper, put in an oven at $180^{\circ} \mathrm{C}$ for 2 hours. Glassware such as measuring pipettes, Petri dishes, measuring cups, $250 \mathrm{~mL}$ Erlenmeyer, glass funnels, test tubes to be used are washed free of detergents, dried and wrapped in coffee paper, then put in an oven at $180^{\circ} \mathrm{C}$ for 1 hour. ${ }^{9}$ The ose is sterilized by way of incubation. ${ }^{10}$

Then the making of Mueller Hinton Agar is made. Mueller Hinton Agar media powder weighed 11.4 grams, then put it in Erlenmeyer, then added $300 \mathrm{~mL}$ of distilled water. After that, it is homogenized with a stirrer over a water bath until it boils. Then sterilized by autoclaving at a temperature of $121^{\circ} \mathrm{C}$ at a pressure of $1 \mathrm{~atm}$ for 15 minutes. After that, Mueller Hinton Agar was removed from the autoclave and cooled until the media temperature was around $\pm 45^{\circ} \mathrm{C}$; the media was evenly poured into sterile Petri dishes as much as $\pm 20 \mathrm{~mL}$ aseptically each. Left at room temperature until solidified, then the media that has compacted its position is reversed to avoid dropping the condensed water on the media. ${ }^{11}$

Furthermore, S.typhi rejuvenation. Media Nutrient Agar is made by taking as much as 0.28 grams dissolved in $10 \mathrm{~mL}$ of distilled water in
Erlenmeyer then covered with aluminum foil. Then heated to boiling and put into a test tube as much as $\pm 3-5 \mathrm{~mL}$ aseptically. Media Nutrient Agar sterilized in an autoclave at a temperature of $121 \mathrm{oC}$ for 15 minutes with a pressure of $1 \mathrm{~atm}$. The media was left at room temperature for 1 hour on its side. One ose of pure S.typhi culture was taken and then scratched on Nutrient Agar media aseptically sloping. The mouth of the tube is brought closer to the fire when striking the bacteria. The tube was then covered with gauze and incubated for 24 hours at $37^{\circ} \mathrm{C} .{ }^{12}$

Then the making of ripe Morinda citrifolia L. extract. Morinda citrifolia $L$., which was ripe, was washed with aqua dest and $70 \%$ alcohol, then drained. Then cut into pieces using a knife washed with $70 \%$ alcohol and heated over a flame. Pieces of Morinda citrifolia L. were dried in direct sunlight. After drying Morinda citrifolia L. was put in a blender that had previously been rinsed with $70 \%$ alcohol. Then the maceration process was carried out in order to obtain $100 \%$ pure Morinda citrifolia $L$. extract. The extract was heated at $56^{\circ} \mathrm{C}$ for 30 minutes in a water bath. ${ }^{13}$ The extracts were grown on Mueller Hinton Agar media which were incubated for 18-24 hours at $37 \mathrm{oC}$ to ensure that the extract was free from bacterial contamination. ${ }^{14}$ Then the Morinda citrifolia L. extract was diluted with aqua dest or sterile physiological $\mathrm{NaCl}$ into several concentrations as needed.

Furthermore, the various concentrations of Morinda citrifolia L. extract were made. The various Morinda citrifolia L. extract concentrations were made by diluting $100 \%$ noni fruit extract using a sterile solution of distilled water or physiological $\mathrm{NaCl}$ to obtain a concentration of $80 \%$, $60 \%, 40 \%$. The dilution is carried out according to Table 1 .

Then making the standard Mc. Farland. Before making the bacterial suspension, it is necessary to make Mc Farland 0.5 solution, namely $9.95 \mathrm{ml} 1 \% \mathrm{H}_{2} \mathrm{SO}_{4}$ plus $0.05 \mathrm{ml} \mathrm{BaCl}_{2} 1 \%$. A dry and sterile test tube is provided, then $10 \mathrm{ml}$ of $0.85 \%$ sterile $\mathrm{NaCl}$ are inserted into the test tube. The suspension was made from pure culture colonies of S. Typhi by taking several colonies using ose.

Furthermore, it is mixed in the test tube until it is equal to the Mc Farland standard of 0.5 . The number of bacteria was obtained about 1.5 $\mathrm{x} 10^{8}$ germs $/ \mathrm{ml}$. For fast processing, it can be done using a Nefelometer set to the standard $0.5 \mathrm{Mc}$ Farland. The turbidity of the bacteria was then measured to show the number 0.5 .

Then the preliminary test. Two sets of tube racks were prepared to contain four dry and sterile test tubes, each labeled and S.typhi suspension equivalent to the Mc Farland standard of 0.5. Each concentration of ripe Morinda citrifolia L. Extract (40\%, 60\%, 80\%, and $100 \%$ ) was piped into a sterile test tube labeled with $5 \mathrm{~mL}$ each volume using a sterile measuring pipette. The bacterial suspension was inserted into each tube as much as $0.1 \mathrm{~mL}$, homogenized, then the stopwatch was turned on. After recording the contact time (15 minutes, 30 minutes, 45 minutes, and 60 minutes) on the ripe Morinda citrifolia L. extract, the suspension was taken one ose, then scratched on Mueller Hinton Agar media. As a comparison, a negative control was made using S.Typhi suspension, which was scratched on Mueller Hinton Agar media, and positive control was made by scratching sterile aqua dest on Mueller Hinton Agar media. Then Mueller Hinton Agar media was incubated at $37 \mathrm{oC}$ for $18-24$ hours. After incubation, the growth of S. Typhi colonies on Mueller Hinton Agar media. ${ }^{15}$

Then the implementation of the minimum inhibitory concentration test. Suppose the observations show that there is no growth of bacterial colonies at all concentrations and contact times. In that case, it is followed by a minimum inhibitory concentration test, namely by diluting the extract of Morinda citrifolia L. starting from $10 \%, 20 \%$, $30 \%$, and $40 \%$. 
Table 1: Preparation of extract concentration variations Morinda citrifolia $L$.

\begin{tabular}{cccc}
\hline No. Label & Aquadest Sterile $(\mathrm{ml})$ & Ekstract Morinda citrifolia L. $(\mathrm{ml})$ & Final Concentration (\%) \\
\hline 1 & 3,0 & $2 \mathrm{ml}$ & $40 \%$ \\
2 & 2,0 & $3 \mathrm{ml}$ & $60 \%$ \\
3 & 1,0 & $4 \mathrm{ml}$ & $80 \%$ \\
4 & - & $5 \mathrm{ml}$ & $5 \mathrm{ml}$ \\
\end{tabular}

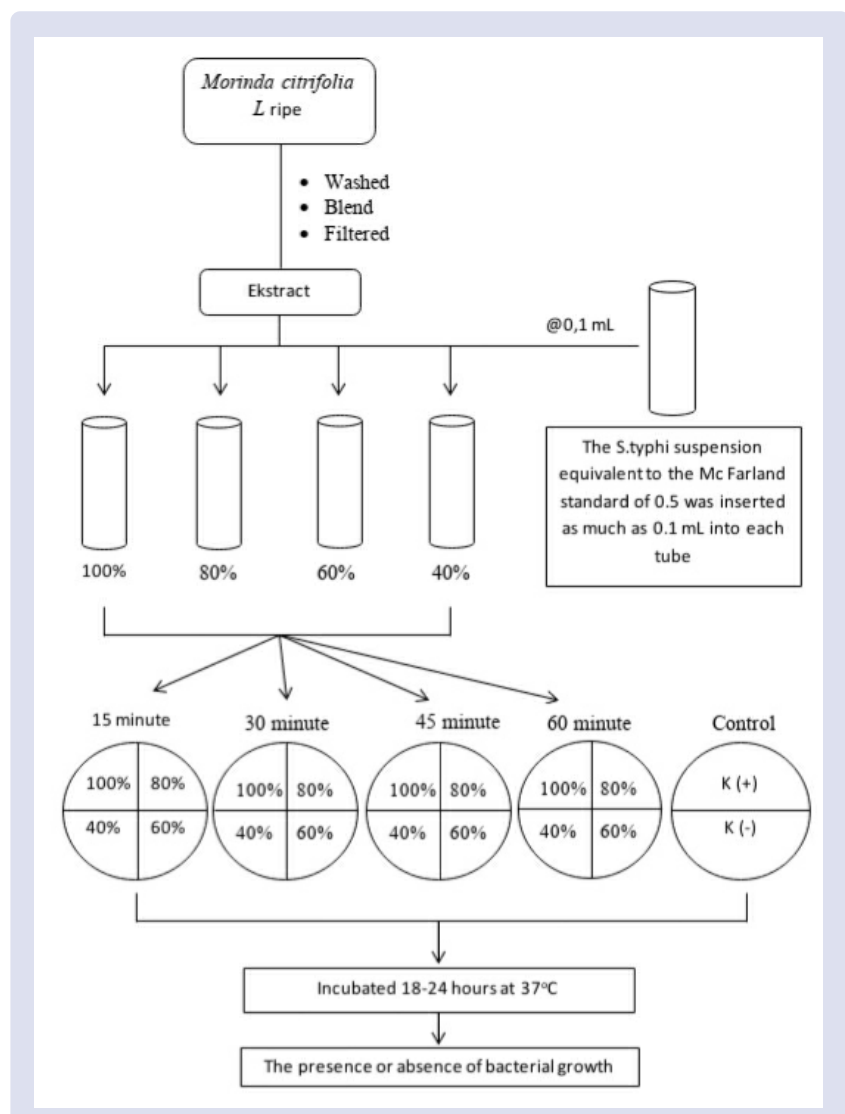

Figure 1: Preliminary test implementation scheme.

\section{RESULTS AND DISCUSSION}

Research conducted on the inhibition of Morinda citrifolia L. extract at concentrations of $40 \%, 60 \%, 80 \%$, and $100 \%$ with variations in contact time 15 ', 30', 45 'd1n 60'. The data obtained from the research results are entered in Table 2.

Based on the results of the observations in Table 3, where at all concentrations and contact times, there was no growth of the tested bacterial colonies. The growth of the tested bacterial colonies showed that it still had anti-bacterial power at the lowest concentration of $40 \%$.

The research was continued with the dilution of Morinda citrifolia $L$. extract starting from $40 \%, 30 \%, 20 \%$, and $10 \%$. Furthermore, the diluted extract of Morinda citrifolia L. was tested to inhibit the growth of the tested bacteria with a variation of contact time of 15 ', 30', 45 ', and 60.'

The data obtained from the test results are included in Table 3.

Based on the study results, data were obtained at all concentrations of Morinda citrifolia L. extract. All variations of contact time showed no growth of S.Typhi colonies in seed media; this indicates that the section of Morinda citrifolia $L$. at each concentration has antibacterial power. The minimum inhibitory concentration is at a concentration of

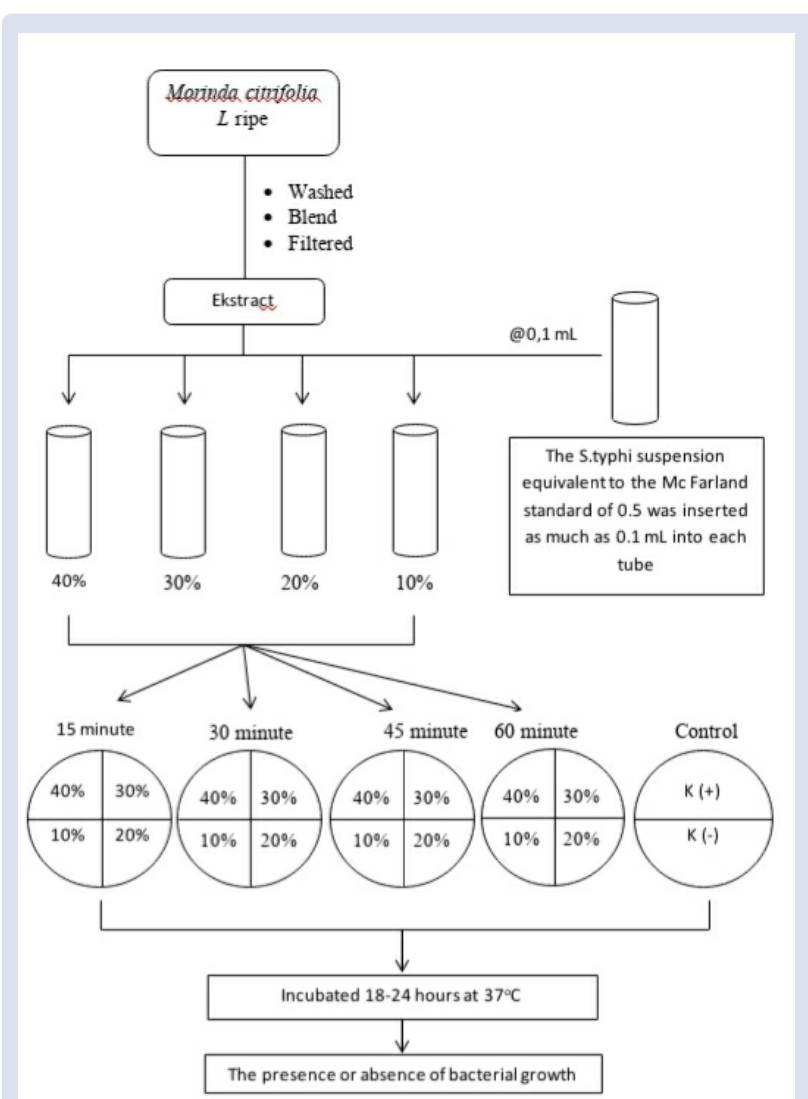

Figure 2: Implementation scheme of minimum inhibitory concentration test.

$10 \%$ with a contact time of 15 minutes which still shows antibacterial activity.

Morinda citrifolia $L$. contains flavonoid and phenol compounds which can function as one of the natural antibacterials. Maturity increases the antioxidant content, total phenol, and ascorbic acid content of Morinda citrifolia $L$. The more mature the total phenol content in Morinda citrifolia L. is getting bigger. ${ }^{6}$ Flavonoids contain phenolic compounds, which are alcoholic acids that are acidic, so it is also called carbolic acid. $^{16}$

The presence of cell wall layers in bacteria affects the activity of antibacterial substances. The phenol component can disrupt the growth of bacterial cells. Phenol can denature proteins and damage cell membranes. The mechanism of action of antibacterial compounds in inhibiting bacterial cells, namely by denaturing bacterial cell proteins, inhibiting cell membrane function (transport of substances from one cell to another), and inhibiting the synthesis of nucleic acids so that bacterial growth can be inhibited. ${ }^{17}$

It is known that the action of antibacterial substances is influenced by several factors, including concentration and duration of contact. Increasing the contact time will increase the chemical reaction between antibacterial and bacteria to inhibit or kill more bacteria. The right concentration and contact time can inhibit or kill bacteria optimally. ${ }^{18}$ 
Table 2: Inhibition of ripe Morinda citrifolia L. extract on S.typhi growth with various concentrations and contact times.

\begin{tabular}{lllllllllll}
\hline & $\mathrm{t}$ & \multicolumn{1}{r}{15 minute } & \multicolumn{3}{c}{30 minute } & \multicolumn{2}{c}{45 minute } & 60 minute & $\mathrm{K}$ & $\mathrm{K}$ \\
$\mathrm{K}$ & 1 & 2 & 1 & 2 & 1 & 2 & & & $(+)$ & $(-)$ \\
\hline $40 \%$ & + & + & + & + & + & + & + & + & & \\
$60 \%$ & + & + & + & + & + & + & + & + & & \\
$80 \%$ & + & + & + & + & + & + & + & + & + & - \\
$100 \%$ & + & + & + & + & + & + & + & + & &
\end{tabular}

Information:

(+) :The absence of colony growth

(-) : There is colony growth.

Table 3: Inhibition of ripe Morinda citrifolia extract on S.typhi growth with various concentrations and contact times.

\begin{tabular}{|c|c|c|c|c|c|c|c|c|c|c|}
\hline \multirow[b]{2}{*}{ K } & \multicolumn{2}{|c|}{15 minute } & \multicolumn{2}{|c|}{30 minute } & \multicolumn{2}{|c|}{45 minute } & \multicolumn{2}{|c|}{60 minute } & \multirow{2}{*}{$\begin{array}{c}\mathrm{K} \\
(+)\end{array}$} & \multirow{2}{*}{$\begin{array}{l}\text { K } \\
(-)\end{array}$} \\
\hline & 1 & 2 & 1 & 2 & 1 & 2 & & & & \\
\hline $10 \%$ & + & + & + & + & + & + & + & + & \multirow{4}{*}{+} & \multirow{4}{*}{ - } \\
\hline $20 \%$ & + & + & + & + & + & + & + & + & & \\
\hline $30 \%$ & + & + & + & + & + & + & + & + & & \\
\hline $40 \%$ & + & + & + & + & + & + & + & + & & \\
\hline
\end{tabular}

Information:

(+) : :The absence of colony growth

$(-) \quad$ :There is colony growth.

Whereas in the study on Morinda citrifolia L., which was ripe and curled, the concentration used was too low, and the contact time used was shorter.

Based on previous research results, it was found that the minimum inhibition level of ripe Morinda citrifolia L. extract against MethicillinResistant Staphylococcus aureus was at a concentration of $30 \%$. In comparison, the minimum kill rate occurred at a concentration of $35 \% .{ }^{14}$ Staphylococcus aureus is a Gram-positive bacteria. ${ }^{19}$ The flavonoids in Morinda citrifolia L. have more excellent inhibitory activity against Gram-positive bacteria because the flavonoid compounds are a polar part. It is easier to penetrate the polar peptidoglycan layer than the non-polar lipid layer, causing inhibitory activity in Gram-negative is smaller than Gram-positive. ${ }^{16}$ S.typhi is a Gram-negative bacterium, has a cell wall with a high lipid content (11-22\%) and a multilayer cell wall structure, namely lipoproteins, phospholipid outer membrane, and lipopolysaccharides. The outer membrane of phospholipids can reduce the entry of antibacterial substances into cells. ${ }^{20}$

The results of research tests regarding the inhibition power of ripe and half-ripe Morinda citrifolia $L$. extracts on the growth of S. Typhi were obtained through observations made with two repetitions. The results showed that the noni fruit extract increased at a concentration of $10 \%$, $20 \%, 30 \%$, and $40 \%$ with a variation of contact time of 15 minutes, 30 minutes, 45 minutes, and 60 minutes, still effective inhibiting the growth of S. Typhi. The results shown are indicated by the absence of colony growth (Table 6 and Table 7). If a bacterium is resistant to an antibacterial, the organism will continue to grow even though antibacterial drugs have been offered. ${ }^{21}$ Resistant bacteria cause the bacteria to be more potent against the antibacterial compounds contained in Morinda citrifolia L.

\section{REFERENCES}

1. Savitri A. Tanaman Ajaib! Basi Penyakit Dengan TOGA (Tanaman Obat Keluarga). Bibit Publisher; 2016.

2. Motshakeri M, Ghazali HM. Nutritional, phytochemical and commercial quality of Noni fruit: A multi-beneficial gift from nature. Trends Food SciTechnol. 2015;45(1):118-129.

3. Suprapti ML. Aneka Olahan Mengkudu. Kanisius; 2009.
4. Brown AC. Anticancer activity of Morinda citrifolia (Noni) fruit: a review. Phyther Res. 2012;26(10):1427-1440.

5. West BJ, Jensen CJ, Westendorf J, White LD. A safety review of non fruit juice. J Food Sci. 2006;71(8):R100-R106.

6. Purwantiningsih TI, Suranindyah YY. Aktivitas senyawa fenol dalam buah mengkudu (Morinda citrifolia) sebagai antibakteri alami untuk penghambatan bakteri penyebab mastitis. Bul Peternak. 2014;38(1):59-64.

7. Kunsah B. Efektifitas Variasi Perasaan Jeruk Nipis (Citrus aurantifolia) Terhadap Pertumbuhan Candida albicans Secara In Vitro. Published online 2016.

8. Nurdeviyanti N. Larutan Garam Dapur Beriodum Menghambat Pertumbuhan Streptococcus mutans secara In Vitro. Progr Pascasarj Univ Udayana. Published online 2011.

9. Karmila K. Daya Hambat Ekstrak Daun Mengkudu (Morinda citrifolia L.) Terhadap Pertumbuhan Bakteri Penyebab Diare. Published online 2016.

10. Affandi A, Andrini F, Lesmana SD. Penentuan Konsentrasi Hambat Minimal dan Konsentrasi BunuhMinimal Larutan Povidon lodium 10\% Terhadap StaphylococcusAureus Resisten Metisilin (MRSA) dan Staphylococcus AureusSensitif Metisilin (MSSA). JIK (Jurnal IImu Kedokteran). 2008;3(1).

11. Yukti AP. PENGARUH EKSTRAK DAUN MENGKUDU (Morinda citrifolia, L.) TERHADAP PERTUMBUHAN JAMUR PENYEBAB KETOMBE Pityrosporum ovale SECARA IN VITRO. SKRIPSI Jur Bio MIPA UM. Published online 2011.

12. Rachmawaty DU Uji aktivitas antibakteri ekstrak etanol, etil asetat dan petroleum eter rambut jagung manis (Zea mays ssaccharata sturt) terhadap bakteri Staphylococcus aureus dan Escherichia coli. Published online 2016

13. Sinarsih NK, Rita WS, Puspawati NM. Uji Efektifitas Ekstrak Daun Trembesi (Samanea saman (jacq.) Merr) Sebagai Antibakteri Escherichia coli dan Staphylococcus aureus. CAKRA Kim (Indonesian E-Journal Appl Chem. 2016:4(2):129-136.

14. Puspitasari, G. SM dan H. Uji Daya Antibakteri Ekstrak Morinda citrifolia L. Matang (Morinda citrifolia) terhadap Bakteri Methicillin Resistan Staphylococcus aureus (MRSA) M.2036.T secara In Vitro. 2012;1-7.

15. FITRIAH-P17335112004 AIN. UJI AKTIVITAS ANTIBAKTERI EKSTRAK ETANOL DAUN JARAK CINA (Jatropha multifida L.) TERHADAP Staphylococcus aureus DENGAN BERBAGAI WAKTU KONTAK. Published online 2019. 
16. Malinggas F. Uji daya hambat ekstrak buah mengkudu (M. citrifolia, L) terhadap pertumbuhan Streptococcus mutans secara in vitro. Pharmacon. 2015;4(4)

17. Locke T, Keat S, Walker A, Mackinnon R. Microbiology and Infectious Diseases on the Move. CRC Press; 2012

18. Risnawati YS. Perbandingan Efek Antibakteri Ekstrak Gambir (uncaria gambir Roxb) Terhadap Streptococcus mutans Pada Konsentrasi dan Waktu Kontak yang Berbeda. Published online 2008.
19. Carroll KC, Butel JS, Morse SA. Jawetz Melnick \& Adelbergs Medical Microbiology 27 E. McGraw-Hill Education; 2015. https://books. google.co.id/books?id=PumOCgAAQBAJ

20. Fatisa Y. Daya antibakteri estrak kulit dan biji buah pulasan (nephelium mutabile) terhadap staphylococcus aureus dan escherichia coli secara in vitro. J Peternak. 2013;10(1).

21. KEE JR, Hayes E. Farmakologi: Pendekatan proses keperawatan. Published online 1996.

\section{GRAPHICAL ABSTRACT}

Morinda cirifolia $L$

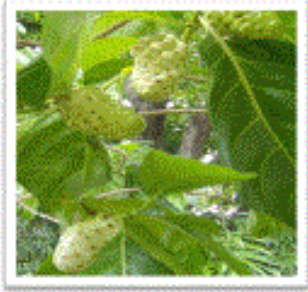

Extraction
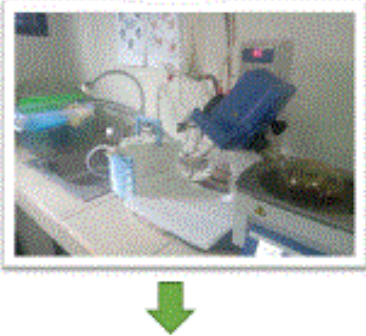

Exctroct Morinda citrifolia $L$.

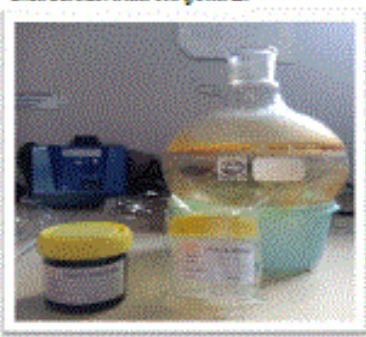

Drying

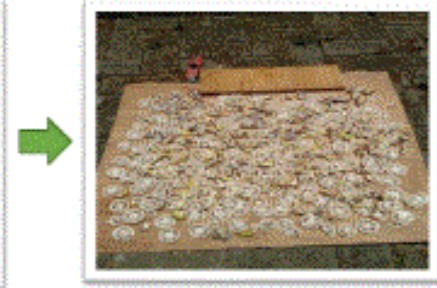

Dilusion

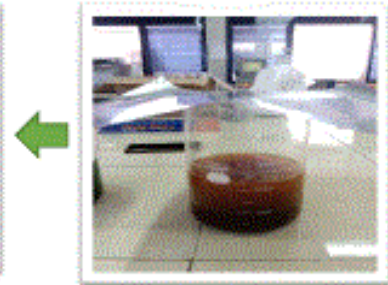

Results of S.typhi bacteria inhibition

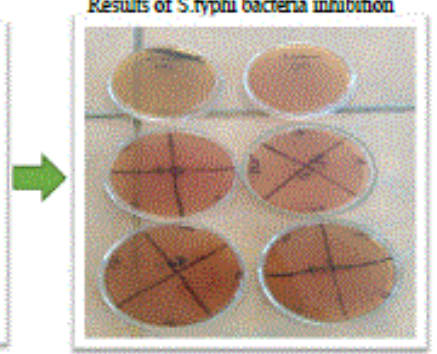

\section{ABOUT AUTHORS}

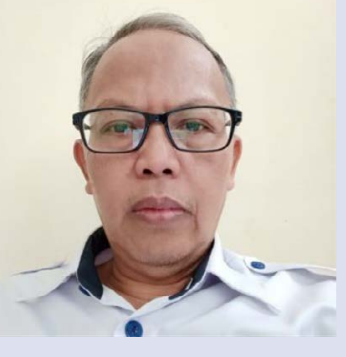

Wawan Sofwan Zaini Lecturer-Researcher in the Department of Medical Laboratory Technology, Health Polytechnic, Ministry of Health, Banten. Specialization in the field of bacteriology and observers / users of family medicinal plants. Has published several research papers on family medicinal plants as herbal medicine and a bacteriology practicum module book.

Cite this article: Zaini WS. Antibacterial Effectiveness of Morinda Citrifolia L. Extract on Salmonella Typhi Bacteria Using Serial Dilution Method with 15 - 60 Minutes Contact Time. Pharmacog J. 2021;13(4): 839-843. 